Bangladesh J. PI. Breed. Genet, 24(1): 23-26

\title{
GENOTYPE SEEDLING AGE INTERACTION FOR HYBRID SEED YIELD OF RICE (Oryza sativa L.)
}

\author{
M. Ariful Islam, U. K. Sarker, M. A. K. Mian and J. U. Ahmed ${ }^{1}$ \\ Department of Genetics and Plant Breeding \\ Bangabandhu Sheikh Mujibur Rahman Agricultural University \\ Gazipur 1706, Bangladesh
}

\begin{abstract}
The experiment was carried out in Randomized Completely Block Design (RCBD) during the Boro season 2006-2007 (Mid October to mid May) at Bangabandhu Sheikh Mujibur Rahaman Agricultural University-Gazipur. Alok showed significant bi but its deviation from regression $\left(S^{2}\right.$ di) invalided its linear prediction. Among the three CMS lines CMS-2 was stable for \% OCR due to considerable mean, phenotypic index, regression coefficient near unity (bi $\approx 1$ ) as well as insignificant deviation from regression $\left(\mathrm{S}^{2} \mathrm{di} \approx 0\right)$ and $\mathrm{CMS}-1$ was highly responsive to seedling ages due to significant bi and insignificant $S^{2}$ di. Although, Alok showed significant bi but its deviation from regression $\left(S^{2} \mathrm{di}\right)$ invalided its linear prediction. Maximum out crossing rate was obtained from CMS-2 irrespective of seedling ages. On the other hand 43 days old seedling of CMS-1 gave the maximum out crossing rate. CMS-2 was highly responsive to yield over seedling ages. CMS-1 showed insignificant regression coefficient (bi) indicating stability over seedling ages but deviation from regression $\left(\mathrm{S}^{2} \mathrm{di}\right)$ was significant which invalided its linear prediction. Alok showed lower mean, significant regression coefficient (bi) and insignificant deviation from regression $\left(S^{2}\right.$ di) indicating responsitive to favourable seedling ages with comparatively lower yield. 43 days old seedlings of CMS-2 gave the maximum hybrid seed production rate.
\end{abstract}

Key words: Rice (Oryza sativa), GxE intraction, CMS, hybrid, seed yield

\section{INTRODUCTION}

Yield stability under a wide range of environmental condition is very important for adaptation of varieties. The yield of a crop plant is a quantitative (polygenic) character and generally influenced by environmental variation. An ideal variety is one that has high mean yield but a low degree of fluctuation in performance when grown over diverse environment. Hence, testing for genotype $\mathrm{x}$ environment interaction has become an important task in the most of the breeding program (Prasad and Singh, 1990). Importance of genotype environment interaction is well established in the field of plant breeding. A successful evaluation of stable genotypes which could be used in future breeding program to develop stable genotypes with a high mean yield but a low degree of fluctuation in performance. It can be done through the study of genotype environment interactions. Stability for widely and specific environments have been assessed by different scientists but information on stability analysis of rice under different

\footnotetext{
${ }^{1}$ Department of Crop Botany, Bangabandhu Sheikh Mujibur Rahman Agricultural University, Gazipur 1706, Bangladesh
} 
environment is little bit of scares. Therefore it is necessary to identify stable genotypes with high mean yield under wide range of environment. Thus genotype $\mathrm{x}$ environment interactions may play an important role and help to select widely adaptable as well as location specific varieties more efficiently. Genotype $\mathrm{x}$ environment interaction implies different behavior of genotypes under different environmental condition (Sarker, 2002).

\section{MATERIALS AND METHODS}

Three promising CMS lines were studied in micro-environments (three different seedling ages: 25days, 34 days and 43 days) for stability analysis. The experimental field was typically rice growing low land of $23^{\circ} 08^{\prime}-24^{\circ} 09^{\prime} \mathrm{N}$ latitude and $90^{\circ} 26^{\prime}-90^{\circ} 82^{\prime}$ longitudes with an elevation of 8.4-8.8 $\mathrm{m}$ from the mean sea level. The soil of the experimental field was Flood plain of Jamuna-Karatoya soil type under Barind Tract in (AEZ 8, 25 \& 28). The experimental site is characterized by heavy rainfall during June to September and minimum rainfall during rest of the year. The temperature ranged during the experimental period $7.9^{\circ} \mathrm{C}-31.8^{0} \mathrm{C}$. The maximum and minimum humidity ranged from $61 \%-96 \%$. The average humidity was around $86 \%$. Three CMS lines, Alok, CMS01 and CMS-02 were used in the study as well as three different seedling ages i.e., seedling age of 25 days, 34 days and 34 days. The phenotypic index (Pi) is used for easy interpretation (Ram et al., 1970). Stability parameters (bi and $\mathrm{S}^{2} \mathrm{di}$ ) were estimated following Eberhart and Russell's model (1966).

\section{RESULTS AND DISCUSSION}

Combined analysis of variance due to environments (seedling age of 25 days, 34 days and 43 days), genotypes and genotype $\mathrm{x}$ seedling age interaction for grain yield and its important component of seed production (out crossing rate) are given in table 1 . The mean sum of squares due to variety was significant for \% OCR and grain yield that revealed the difference among genotypes and their considerable influence in out crossing rate and yield of rice. The environmental (seedling ages) mean sum of square was significant for out crossing rate and yield which revealed the variation of out crossing rate and yield of rice varieties over seedling ages. Sarker et al. (2002) found similar results in their study on stability for grain yield under different planting times in Bangladesh. The significant mean sum of square of genotype $\mathrm{x}$ environment interaction for both the traits indicated the presence of differences among the regression of the genotypes on environmental indices. This result suggests that the analysis could be extended for the stability analysis. The mean sum of squares of interaction between environment + (genotype $\mathrm{x}$ environment) was also significant for out crossing rate and yield which indicated very minute deviation from regression.

Table 1. Pooled analysis of variance for out crossing rate (\% OCR) and grain yield of three CMS lines

\begin{tabular}{l|c|c|c}
\hline Source of variation & df & \multicolumn{2}{|c}{ Mean sum of squares } \\
\cline { 3 - 4 } & & $\%$ OCR & Yield \\
\hline Genotype & 2 & $1.41^{*}$ & $0.16^{*}$ \\
Environment (Seedling ages) & 2 & $16.58^{*}$ & $0.15^{*}$ \\
Genotype x Environment & 4 & $3.67^{*}$ & $0.05^{*}$ \\
Environment + (genotype x Environment) & 6 & $28.83^{*}$ & $0.18^{*}$ \\
Environment (linear) & 1 & $31.89^{* *}$ & $0.81^{* *}$ \\
Genotype x Environment (linear) & 2 & $2.35 \mathrm{~ns}$ & $0.89^{* *}$ \\
Pooled deviation & 3 & 32.64 & 0.08 \\
Pooled error & 12 & 1.65 & 0.02 \\
\hline
\end{tabular}

* and ** significant at $5 \%$ and $1 \%$ level of significance, and $\mathrm{ns}=$ insignificant 
The linear portion of environment mean sum of square was highly significant for out crossing rate and yield (Mannan, 1991). The linear portion of genotype $\mathrm{x}$ environment mean sum of square was insignificant for out crossing rate but it was highly significant for yield. Significant linear components indicating the presence of differences among the regression values of the genotypes on the environmental indices. Insignificant non linear components (pooled deviation) for the traits suggested the stability of the genotypes with the changes of seedling age. It also explains that the production based on regression analysis for the genotypes differed considerably in respect to their stability performance. Das et al. (1991) also found significant linear and non-linear component of the interaction in \%OCR and yield of rice. According to Eberhart and Russell (1966), a stable genotype is characterized by a slope not differ from unity $(\mathrm{bi}=1)$ and the deviation from regression close to zero $\left(S^{2} \mathrm{di}=0\right)$. The stability parameters mean phenotypic index $(\mathrm{Pi})$, regression coefficient (bi) and deviation from regression $\left(\mathrm{S}^{2} \mathrm{di}\right)$ for yield and out crossing rate are presented in table 2 and 3 (Manonmani et al., 1991).

Table 2. Environment wise mean out crossing rate (\% OCR) and estimated stability of three CMS lines

\begin{tabular}{|c|c|c|c|c|c|c|c|}
\hline \multirow[b]{2}{*}{ Genotype } & \multicolumn{3}{|c|}{ Environments (seedling age) } & \multirow[t]{2}{*}{ Mean } & \multirow{2}{*}{$\begin{array}{c}\text { Phenotypic } \\
\text { index } \\
\text { (PI) }\end{array}$} & \multirow{2}{*}{$\begin{array}{l}\text { Regression } \\
\text { coefficient } \\
\text { (bi) }\end{array}$} & \multirow{2}{*}{$\begin{array}{l}\text { deviation from } \\
\text { regression } \\
\left(\mathrm{S}^{2} \mathrm{di}\right)\end{array}$} \\
\hline & $\begin{array}{c}25 \text { days } \\
\text { old }\end{array}$ & $\begin{array}{c}34 \text { days } \\
\text { old }\end{array}$ & $\begin{array}{c}43 \text { days } \\
\text { old }\end{array}$ & & & & \\
\hline Alok & 39.99 & 42.7 & 42.60 & 41.77 & -3.15 & $2.58 *$ & $5.26^{*}$ \\
\hline CMS-1 & 39.04 & 42.93 & 50.32 & 44.09 & -0.83 & $3.91 *$ & $0.72^{\mathrm{ns}}$ \\
\hline CMS-2 & 42.12 & 49.83 & 54.75 & 48.90 & 3.98 & $1.01^{\mathrm{ns}}$ & $0.16^{\mathrm{ns}}$ \\
\hline Env mean & 40.38 & 45.15 & 49.23 & $(\mathrm{GM})$ & & & \\
\hline Env index & -4.54 & 0.23 & 4.31 & 44.92 & & & \\
\hline SE & & 0.24 & & & & & \\
\hline
\end{tabular}

* Significant at $5 \%$ and $\mathrm{ns}=$ insignificant

The linear portions of $\mathrm{G} \times \mathrm{E}$ interaction was significant and non linear portions was insignificant for both out crossing rate and grain yield ( $\mathrm{t} / \mathrm{ha}$ ) but in case of individual test, Alok exhibited significant deviation from regression $\left(\mathrm{S}^{2} \mathrm{di}\right)$ for \% OCR and CMS-1 exhibited significant deviation from regression $\left(\mathrm{S}^{2} \mathrm{di}\right)$ for yield, thus stability appears to be the property of individual buffering rather than population buffering for these characters. From the environmental index it was clear that 43 days old seedlings were suitable for favorable environments for \% OCR (Rashid et al., 1991). Among the three CMS lines CMS-2 was stable for \% OCR due to considerable mean, phenotypic index, regression coefficient near unity $(\mathrm{bi} \approx 1)$ as well as insignificant deviation from regression $\left(\mathrm{S}^{2} \mathrm{di} \approx 0\right)$ and CMS-1 was highly responsive to seedling ages due to significant bi and insignificant $\mathrm{S}^{2}$ di. Although, Alok showed significant bi but its deviation from regression $\left(\mathrm{S}^{2} \mathrm{di}\right)$ invalided its linear prediction (table 2). Maximum out crossing rate was obtained from CMS-2 irrespective of seedling ages (Rao et al., 1991). On the other hand 43 days old seedling of CMS-1 gave the maximum out crossing rate. CMS-2 was highly responsive to yield over seedling ages as judge through high mean, phenotypic index, significant regression coefficient (bi) and insignificant $\left(\mathrm{S}^{2} \mathrm{di}\right)$. CMS-1 showed insignificant regression coefficient (bi) indicating stability over seedling ages but deviation from regression $\left(\mathrm{S}^{2} \mathrm{di}\right)$ was significant which invalided its linear prediction (Table 3). 
Table 3. Environment wise mean yield and estimated stability of three CMS lines

\begin{tabular}{|c|c|c|c|c|c|c|c|}
\hline \multirow[t]{2}{*}{ Genotype } & \multicolumn{3}{|c|}{ Environments (seedling age) } & \multirow[t]{2}{*}{ Mean } & \multirow{2}{*}{$\begin{array}{c}\text { Phenotypic } \\
\text { index } \\
\text { (PI) }\end{array}$} & \multirow{2}{*}{$\begin{array}{l}\text { Regression } \\
\text { coefficient } \\
\text { (bi) }\end{array}$} & \multirow{2}{*}{$\begin{array}{l}\text { deviation from } \\
\text { regression } \\
\left(\mathrm{S}^{2} \mathrm{di}\right)\end{array}$} \\
\hline & $\begin{array}{l}25 \text { days } \\
\text { old }\end{array}$ & $\begin{array}{c}34 \text { days } \\
\text { old }\end{array}$ & $\begin{array}{c}43 \text { days } \\
\text { old }\end{array}$ & & & & \\
\hline Alok & 3.10 & 3.08 & 3.36 & 3.18 & -0.37 & $0.83^{*}$ & $-1.25^{\mathrm{ns}}$ \\
\hline CMS-1 & 3.32 & 3.42 & 3.62 & 3.44 & -0.11 & $0.36^{\mathrm{ns}}$ & $1.11 *$ \\
\hline CMS-2 & 4.04 & 3.84 & 4.21 & 4.03 & 0.48 & $0.93 *$ & $-0.21^{\mathrm{ns}}$ \\
\hline Env mean & 3.48 & 3.44 & 3.73 & $(\mathrm{GM})$ & & & \\
\hline Env index & -0.07 & -0.11 & 0.18 & 3.55 & & & \\
\hline SE & & 0.03 & & & & & \\
\hline
\end{tabular}

Alok showed lower mean, significant regression coefficient (bi) and insignificant deviation from regression $\left(\mathrm{S}^{2}\right.$ di) indicating responsitive to favourable seedling ages with comparatively lower yield. 43 days old seedlings of CMS-2 gave the maximum hybrid seed production rate.

\section{REFERENCES}

Das, S. C. and S. C. Debnath. 1991. Heterosis for rain yield and plant height in Maize. J. Agril. Sci. 17: 179-184.

Eberhart, S. A. and W. A. Russell. 1966. Stability parameters for comparing varieties. Crop Sci. 6: 36-40.

Prasad, K. V. and R. L. Singh. 1990. Stability analysis of yield and yield components and construction of selection indices of direct seeded rice in frost season. Annual Review conference Proceeding. 20-23 October 1992. National Agril. Res. Inst. Caribbean Agricultural Research and development Institute, Guyana. p. 63-71.

Ram, J., O. P. Jain and B. R. Murty, 1970. Stability performance of some varieties and hybrid derivatives in rice under high yielding varieties program Indian J. Genet. PI. Breed. 30: 187-198.

Sarker, U., P. S. Biswas, B. Prasad and M. A. K. Main. 2002. Stability for grain yield under different planting times in Bangladesh. Bangladesh J. Agril. Res. 27(3): 425-430.

Rashid, M. A., M. L. Aragon and G. L. Denning, 1990. Influence of variety, seedling age and nitrogen level on growth and yield of rice grown on saline soil. Bangladesh Rice J. 1: 37-47.

Rao, K. S., B. T. S. Moorthy, A. B. Dash and S. B. Lodh. 1997. Effect of time of transplanting on grain yield and quality traits of Basmati-type scented rice (Oryza sativa) varieties in coastal Orissa. Indian J. Agril. Sci. 66(6): 333-337.

Mannan, M. A. 1991. Stability effect of seedling ages and date of planting on the growth and yield of photo-period sensitive rice. Bangladesh Rice J. 2: 101-102.

Manonmani, S. T., B. Ranganathan and R. Narasimman. 1999. Effect of seedling age in earliness and yield components in rice. Madras Agril. J. 86: 124-126. 